\title{
The Effect of Work Discipline and Motivation on Employee Performance at PT. Karuna Intermedia
}

\author{
Iman Syatoto \\ Universitas Pamulang \\ E-mail: imansyatoto@gmail.com
}

(Received: December-2018; Reviewed: January-2019; Accepted: February-2019;

Avalaibel Online: February-2019; Published: March-2019)

cc (i) (2) This is an open access article distributed under the Creative Commons Attribution License EY CC-BY-NC-4.0 (C2019 by author (https://creativecommons.org/licenses/by-nc/4.0/)

\begin{abstract}
Human Resources (HR) is the most vital resource that determines the success of a company. The purpose of this study was to determine the effect of discipline and work discipline on employee work performance. The method used is descriptive method with an associative approach. The sampling technique used was proportional random sampling using the method of saturated sampling technique with a sample of 40 respondents. The analysis tool uses validity test, reliability test, classic assumption test, regression test, correlation coefficient test, coefficient of determination test and hypothesis test. The result of this study is that work discipline has a positive and significant effect on employee performance by $49.7 \%$. Hypothesis testing is obtained $t_{\text {count }}>t_{\text {table }}$ or $(6.131>2.024)$, so that $\mathrm{H} 0$ is rejected and $\mathrm{H} 1$ is accepted meaning that there is a positive and significant influence between discipline on employee work performance. discipline has a positive and significant effect on employee performance by $45.4 \%$. Hypothesis testing is obtained $t_{\text {count }}>t_{\text {table }}$ or $(5.625>2.024)$ so that $\mathrm{H} 0$ is rejected and $\mathrm{H} 2$ is accepted, meaning that there is a positive and significant influence between discipline on employee work performance. A simultaneous test of work discipline and discipline has a positive and significant effect on employee performance with a contribution of $58.2 \%$, while the remaining $41.8 \%$ is influenced by other factors. Hypothesis testing obtained the value of $F_{\text {coun }}>F_{\text {table }}$ or $(25.798>2.860) \mathrm{g}$ thus Ho is rejected and $\mathrm{H} 3$ is accepted. This means that there is a positive and significant effect simultaneously between discipline and work discipline on employee work performance.
\end{abstract}

Keywords: Work discipline; motivation; employee performance

\section{INTRODUCTION}

One of the goals of the development of the Indonesian nation is to raise the standard of living and welfare of all the people of Indonesia. In realizing this, efforts taken by the government include encouraging and supporting the growth of various industries, both in the government and private sectors (Artiani, 2011; Solikatun, Supono, \& Masruroh, 2014). With the continued progress of economic and technological activities that will continue to take effect 
will result in increasingly complex problems faced by companies at this time. In this case, every company needs human resources who have high performance, so that it can provide maximum results for the company (Hasibuan, 2011; A. A. A. P. Mangkunegara, 2003; Marwansyah, 2010). So that companies can compete, the demand for awareness of the importance of the quality of Human Resources (HR) which is one of the responses in addressing these changes is very important. Quality Human Resources (HR) is very important for a company. Even the availability of quality human resources is believed to be the main key to success (Handoko, 2010; M.Pd, 2016; Mathis Robert \& Jackson John, 2001; Sakban, Nurmal, \& Bin Ridwan, 2019).

Human Resources (HR) is the most vital resources that determine the success of a company, therefore it needs to be given rights that can spur improve its performance, there are several factors that can encourage employees to improve their performance, one of which is the provision of discipline by the leader in the company to employees (A. P. Mangkunegara \& Octorend, 2015; Purnama \& Kempa, 2016; Rahadi, 2010; Sunarsi, 2014, 2017, 2018a, 2018b, 2018c). Good discipline reflects the magnitude of one's sense of responsibility for the tasks assigned to him (Purnama \& Kempa, 2016; Reza, 2010; Rukhayati, 2018). This encourages workplace passion, and the realization of company, employee and community goals. Therefore, every manager always tries to have good discipline in his subordinates. A manager is said to be effective in his leadership if his employees are well disciplined. To maintain and improve good discipline is difficult. To get the human resources expected by the organization to contribute positively to all company activities in achieving its goals, each employee is expected to have high work discipline so that later it will increase high performance (Hidayat \& Taufik, 2012; Jeli Nata Liyas \& Primadi, 2017; Septiasari, 2017; Yoesana, 2013).

Given the importance of discipline for each employee, the company needs to continue to maintain that employee discipline does not decrease. One thing that every employee needs to understand is working because he wants to meet his needs, both the needs that are realized and the needs that are not realized. Meeting these needs will certainly discipline employees at work to increase and have an impact on a good performance and help the company achieve its goals.

\section{METHOD}

The type of data used is quantitative with primary data sources by distributing questionnaires which are then carried out tabulation and feasibility analysis as well as secondary data from the various scientific literature. The population in this study were employees of PT. Karuna Intermedia. Sampling was used as a saturated sampling technique that is 60 employees. The instrument testing uses validity and reliability tests. From the validity and reliability test stated valid and reliable, this is evidenced by the value of $r$ count $>r$ table, likewise, the instrument used is appropriate and feasible to be forwarded to the next test. Testing for normality using Kolmogorov Smirnov obtained significance greater than 0.50 and thus declared normal. Multicollinearity testing obtained tolerance values $<1$ and IF $<10$ so that it was concluded there was no interference with multicollinearity. Autocorrelation testing obtained the value of Durbin-Watson at an interval of $1.550-2.460$, thus this regression model does not have autocorrelation. Heteroskesdastisitas testing with Glejser test obtained significance values greater than 0.05 so it was concluded that there was no interference with heteroscedasticity.

\section{RESULT AND DISCUSSION}

Since its establishment in 1995, PT. Karuna Intermedia now has approximately 40 employees with a number of customers reaching approximately 2,000 per year. With increasingly fierce competition. PT. Karuna Intermedia. Must try to improve performance in order to gain 
confidence from the community, so that all activities are achieved in accordance with expectations

\section{Multiple Linear Regression Analysis.}

This multiple regression test is intended to find out how much influence the variables $\mathrm{X} 1$ and $\mathrm{X} 2$ on the $\mathrm{Y}$ variable. In this study work discipline (X1) and motivation (X2) on employee performance $(\mathrm{Y})$. The following are the results of processed regression data with SPSS version 24 which can be seen in the following table:

Table 1.

Results of Multiple Regression Processing Work Discipline Variables (X1) and Motivation (X2) on Employee Performance (Y)

\section{Coefficients $^{\mathrm{a}}$}

\begin{tabular}{|c|c|c|c|c|c|c|}
\hline \multirow{2}{*}{\multicolumn{2}{|c|}{ Model }} & \multicolumn{2}{|c|}{ Unstandardized Coefficients } & $\begin{array}{l}\text { Standardized } \\
\text { Coefficients }\end{array}$ & \multirow[b]{2}{*}{$\mathrm{t}$} & \multirow[b]{2}{*}{ Sig. } \\
\hline & & $\mathrm{B}$ & Std. Error & Beta & & \\
\hline \multirow[t]{3}{*}{1} & (Constant) & 9,410 & 4,235 & & 2,222 &, 032 \\
\hline & Work Discipline (X1) & ,419 &, 124 & ,464 & 3,368 &, 002 \\
\hline & Motivation (X2) & ,350 & , 127 & ,378 & 2,746 & ,009 \\
\hline
\end{tabular}

a. Dependent Variable: Employee Performance (Y)

Based on the results of the regression calculations in the above table, the regression equation $\mathrm{Y}=9,410+0,419 \mathrm{X} 1+0,350 \mathrm{X} 2$ can be obtained. A constant value of 9,410 means that if the variables of work discipline (X1) and motivation (X2) are absent then there is an employee performance value (Y) of 9,410 points. A value of 0.419 is interpreted if the constant is constant and there is no change in the motivation variable (X2), then every 1 unit change in the work discipline variable (X1) will result in a change in employee performance (Y) of 0.419 points. A value of 0.350 is interpreted if the constant is constant and there is no change in the work discipline variable work discipline (X1), then every 1 unit change in the motivation variable $(\mathrm{X} 2)$ will result in changes in employee performance $(\mathrm{Y})$ of 0.350 points.

\section{Analysis of the Coefficient of Determination (R Square).}

Analysis of the coefficient of determination is intended to find out the percentage strength of the relationship between the independent variables on the dependent variable both partially and simultaneously), in this study is the variable work discipline (X1) and motivation (X2) on employee performance (Y). Following are the results of the calculation of the coefficient of determination processed with SPSS version 24, as follows:

Table 2.

Results of Partial Determination Coefficient Analysis Between Work Discipline Variables (X1) Against Employee Performance (Y)

\section{Model Summary}

\begin{tabular}{|c|c|c|c|c|}
\hline & & & Adjusted R & \\
\hline Model & $\mathrm{R}$ & R Square & Square & Std. Error of the Estimate \\
\hline 1 &, $705^{\mathrm{a}}$ & ,497 &, 484 & 2,544 \\
\hline
\end{tabular}


Based on the test results in the table above, R-square value (determination coefficient) of 0.497 is obtained, it can be concluded that the Work Discipline variable (X1) influences the employee Performance variable (Y) of $49.7 \%$ while the remaining $50.3 \%$ influenced by other factors.

Table 3.

Partial Results of the Coefficient of Determination Analysis Between Motivation Variables (X2) Against Employee Performance (Y)

Model Summary

\begin{tabular}{lrrrr}
\hline Model & R & R Square & Adjusted R Square & Std. Error of the Estimate \\
\hline 1 &, $674^{\mathrm{a}}$ &, 454 &, 440 & 2,650 \\
\hline a. Predictors: (Constant), Motivasi (X2) & & &
\end{tabular}

Based on the test results in the above table, R-square value of 0.454 is obtained, it can be concluded that the motivation variable (X2) influences the employee performance variable (Y) of $45.4 \%$ while the remaining $54.6 \%$ is influenced by other factors.

Table 4.

Simultaneous Determination Coefficient Analysis Results Work Discipline (X1) and Motivation (X2) on Employee Performance (Y)

\section{Model Summary}

\begin{tabular}{|c|c|c|c|c|}
\hline & & & Adjusted R & \\
\hline Model & $\mathrm{R}$ & R Square & Square & Std. Error of the Estimate \\
\hline 1 &, $763^{\mathrm{a}}$ &, 582 &, 560 & 2,350 \\
\hline
\end{tabular}

Based on the test results in the above table, the R-square value of 0.582 is obtained, so it can be concluded that the disciplinary variable (X1) and work discipline (X2) influence the employee performance variable $(\mathrm{Y})$ of $58.2 \%$ while the remaining $41.8 \%$ is influenced by other factors that were not carried out by the study.

\section{Hypostesis Test}

To test the hypothesis of work discipline variables (X1) and motivation (X2) on employee performance $(\mathrm{Y})$ performed with a statistical test $\mathrm{t}$ (partial test). The test results are as follows:

Table 5.

T-Test Results for Work Discipline Variables (X1)

\section{Coefficients $^{\mathrm{a}}$}

\begin{tabular}{|c|c|c|c|c|c|c|}
\hline \multirow{2}{*}{\multicolumn{2}{|c|}{ Model }} & \multicolumn{2}{|c|}{$\begin{array}{l}\text { Unstandardized } \\
\text { Coefficients }\end{array}$} & \multirow{2}{*}{$\begin{array}{c}\text { Standardized } \\
\text { Coefficients } \\
\text { Beta } \\
\end{array}$} & \multirow[b]{2}{*}{$\mathrm{t}$} & \multirow[b]{2}{*}{ Sig. } \\
\hline & & $\mathrm{B}$ & Std. Error & & & \\
\hline 1 & (Constant) & 14,502 & 4,122 & & 3,518 &, 001 \\
\hline & Work Discipline (X1) & 637 & ,104 & ,705 & 6,131 &, 000 \\
\hline
\end{tabular}

Based on the test results in the above table, the value of $t_{\text {count }}>t_{\text {table }}$ or $(6.131>2.024)$ is also strengthened by the value of $\rho$ value $<$ Sig. 0.05 or $(0,000<0.05)$. Thus, H0 is rejected and H1 is accepted. 
Table 6.

T-Test Results for Motivational Variables (X2)

Coefficients $^{\mathrm{a}}$

\begin{tabular}{|c|c|c|c|c|c|c|}
\hline \multirow[b]{2}{*}{ Model } & & \multicolumn{2}{|c|}{$\begin{array}{l}\text { Unstandardized } \\
\text { Coefficients }\end{array}$} & $\begin{array}{c}\text { Standardized } \\
\text { Coefficients }\end{array}$ & \multirow[b]{2}{*}{$\mathrm{t}$} & \multirow[b]{2}{*}{ Sig. } \\
\hline & & $\mathrm{B}$ & Std. Error & Beta & & \\
\hline 1 & (Constant) & 15,271 & 4,354 & & 3,507 &, 001 \\
\hline & Motivation (X2) & ,624 &, 111 & 674 & 5,625 &, 000 \\
\hline
\end{tabular}

Based on the test results in the above table, the value of $t_{\text {count }}>t_{\text {table }}$ or $(5.625>2.024)$ is also strengthened by the value of $\rho$ value $<$ Sig. 0.05 or $(0,000<0.05)$. Thus, $\mathrm{H} 0$ is rejected and $\mathrm{H} 2$ is accepted

To test the effect of work discipline and discipline variables simultaneously on employee performance is carried out by the statistical test $\mathrm{F}$ (simultaneous test) with a significance of $5 \%$.

Table 8.

Simultaneous Hypothesis Results (F-Test)

ANOVA $^{\mathrm{a}}$

\begin{tabular}{llrrrrr}
\hline Model & & Sum of Squares & df & Mean Square & F & Sig. \\
\hline \multirow{2}{*}{1} & Regression & 284,838 & 2 & 142,419 & 25,798 &, $000^{\text {b }}$ \\
\cline { 2 - 7 } & Residual & 204,262 & 37 & 5,521 & & \\
\cline { 2 - 7 } & Total & 489,100 & 39 & & & \\
\hline
\end{tabular}

Based on the test results in the above table, the calculated $\mathrm{F}_{\text {count }}>\mathrm{F}_{\text {table }}$ or $(25.798>2.860)$ is also strengthened by the $\rho$ value $<$ Sig. 0.05 or $(0,000<0.05)$. Thus, $\mathrm{H} 0$ is rejected and $\mathrm{H} 3$ is accepted, this shows that there is a positive and significant effect simultaneously between work discipline and discipline on employee performance in the discipline.

\section{CONCLUSION}

Based on the results of the study found that work discipline has a positive and significant effect on employee performance with a correlation value of 0.705 which means it has a strong influence. Motivation has a positive and significant effect on employee performance with a correlation value of 0.674 which means it has a strong influence. Work discipline and motivation have positive and significant effect on employee performance with a regression equation $\mathrm{Y}=9,410+0,419 \mathrm{X} 1+0,350 \mathrm{X} 2$. The value of determination was $58.2 \%$ while the remaining $41.8 \%$ was influenced by other factors. Hypothesis testing obtained the value of $F_{\text {count }}>F_{\text {table }}$ or $(25.798>2.860)$, it is also strengthened with a probability of $0,000<0.05$. Thus $\mathrm{H} 0$ is rejected and $\mathrm{H} 3$ is accepted. This means that there is a positive and significant effect simultaneously between work discipline and discipline on employee performance.

\section{REFERENCES}

Artiani, L. E. (2011). Dampak Ekonomi Makro Bencana : Interaksi Bencana dan Pembangunan Ekonomi Nasional. Seminar Nasional Informatika 2011.

Handoko, H. (2010). Manajemen Personalia Sumber Daya Manusia, Edisi Kedua. In BPFE UGM Persada. https://doi.org/10.4324/9780203488430

Hasibuan, M. S. P. (2011). Manajemen Sumber Daya Manusia. Edisi Revisi Jakarta: Bumi 
Aksara.

Hidayat, Z., \& Taufik, M. (2012). Pengaruh Lingkungan Kerja dan Disiplin Kerja serta Motivasi Kerja Terhadap Kinerja Karyawan Perusahaan Daerah Air Minum (PDAM) Kabupaten Lumajang. Jurnal WIGA.

Jeli Nata Liyas, \& Primadi, R. (2017). Pengaruh Disiplin Kerja Terhadap Kinerja Karyawan Pada Bank Perkreditan Rakyat. Al Masraf. https://doi.org/10.1016/j.nanoen.2012.08.008

M.Pd, E. (2016). Manajemen Pelatihan Sumber Daya Manusia Dalam Meningkatkan Mutu Lulusan. EduTech: Jurnal Ilmu Pendidikan dan Ilmu Sosial.

Mangkunegara, A. A. A. P. (2003). Manajemen Sumber Daya Manusia Perusahaan. In Remaja Rosdakarya. https://doi.org/10.1038/cddis.2011.1

Mangkunegara, A. P., \& Octorend, T. R. (2015). Effect of Work Discipline, Work Motivation and Job Satisfaction on Employee Organizational Commitment in the Company (Case Study in PT. Dada Indonesia). Universal Journal of Management. https://doi.org/10.13189/ujm.2015.030803

Marwansyah. (2010). Manajemen Sumber Daya Manusia. Alfabeta: Jakarta. https://doi.org/10.1017/CBO9781107415324.004

Mathis Robert, L., \& Jackson John, H. (2001). Manajemen Sumber Daya Manusia Buku 1. Edisi Pertama, Penerbit Salemba Empat, Jakarta.

Purnama, C., \& Kempa, S. (2016). Pengaruh Kompetensi Dan Disiplin Kerja Terhadap Kinerja Karyawan. Journal Manajemen Manajemen.

Rahadi, D. R. (2010). Manajemen Kinerja Sumber Daya Manusia. In Applied Physics A: Materials Science and Processing. https://doi.org/10.1007/s00339-002-1913-7

Reza, R. A. (2010). Pengaruh Gaya Kepemimpinan, Motivasi dan Disiplin Kerja Terhadap Kinerja Karyawan PT Sinar Santosa Perkasa Banjarnegara. Pengaruh Gaya Kepimpinan, Motivasi Dan Disiplin Kerja Terhadap Kinerja Karyawan Pt Sinar Santosa Perkasa Banjarnegara.

Rukhayati. (2018). Pengaruh Motivasi Dan Disiplin Kerja Terhadap Kinerja Karyawan Di Puskesmas Talise. Jurnal Sinar Manajemen.

Sakban, S., Nurmal, I., \& Bin Ridwan, R. (2019). Manajemen Sumber Daya Manusia. Journal of Administration and Educational Management (Alignment). https://doi.org/10.31539/alignment.v2i1.721

Septiasari, D. D. (2017). Pengaruh Disiplin Kerja Terhadap Kinerja Pegawai Pada Dinas Perindustrian Perdagangan, Koperasi, dan Usaha Mikro Kecil dan Menengah Provinsi Kalimantan Timur di Samarinda (Bidang Sekretariat dan Bidang Industri). eJournal Administrasi Bisnis.

Solikatun, Supono, \& Masruroh, Y. (2014). Kemiskinan Dalam Pembangunan. Jurnal Analisa Sosiologi. https://doi.org/10.20961/jas.v3i1.17450

Sunarsi, D. (2014). Pengaruh Gaya Kepemimpinan, Disiplin dan Motivasi Terhadap Kinerja. Tesis. Fakultas Ekonomi Universitas Pamulang.

Sunarsi, D. (2017). Pengaruh Disiplin, Motivasi, Dan Kompetensi Terhadap Prestasi Belajar (Studi Kasus Pada Mahasiswa Universitas Pamulang, Tangerang Selatan Tahun Akademik 2016-2017). Jurnal Mandiri: Ilmu Pengetahuan, Seni, dan Teknologi, 1(2), 207-226. 
Sunarsi, D. (2018a). Pengaruh Gaya Kepemimpinan, Motivasi Dan Disiplin Kerja Terhadap Kinerja Pendidik Yayasan Marvin. Inovasi, 5(1), 1-18.

Sunarsi, D. (2018b). Pengaruh Gaya Kepemimpinan dan Disiplin Kerja Terhadap Kinerja Karyawan Pada CV. Usaha Mandiri Jakarta. JENIUS, 1(2).

Sunarsi, D. (2018c). Pengaruh Motivasi Dan Disiplin Terhadap Produktivitas Kerja Karyawan Pada PT. Nadi Suwarna Bumi. Jurnal Semarak, 1(1).

Yoesana, U. (2013). Hubungan Antara Motivasi Kerja Dengan Disiplin Kerja Pegawai di Kantor Kecamatan Muara Jawa Kabupaten Kutai Kartanegara. eJournal Pemerintahan Integratif. 
118 Pinisi Discretion Review

Volume 2, Issue 2, March, 2019. Pages 111-118 